\title{
Evaluation of the antibacterial activity of mango ginger rhizome extracts against bacterial wilt pathogen Ralstonia solanacearum
}

R Karthika, D Prasath*, N K Leela, R Suseela Bhai \& M Anandaraj

ICAR-Indian Institute of Spices Research, Kozhikode-673 012, Kerala.

*E-mail: dprasath@gmail.com

Received 15 April 2017; Revised 26 May 2017; Accepted 31 May 2017

\begin{abstract}
The Indian mango ginger (Curcuma amada Roxb.) is a perennial rhizomatous herb with a raw mango flavour. It is resistant to bacterial wilt disease. In order to understand the disease resistance mechanism of mango ginger the hexane, chloroform and methanol extracts $(5,10,25,50$ and 100 $\left.\mathrm{mg} \mathrm{mL}^{-1}\right)$ and essential oils $(1 \%, 5 \%$ and $10 \%)$ were tested against the bacterial wilt pathogen Ralstonia solanacearum by agar well diffusion method. The hexane, chloroform and methanol extracts showed more or less the same level of antimicrobial activity with a zone of inhibition ranging from 3-9 $\mathrm{mm}$. The essential oils exhibited a zone of inhibition ranging from 3-7 $\mathrm{mm}$. The major constituents of the essential oils were $\beta$-myrcene and $\beta$-pinene. The results indicated that the rhizome of mango ginger may contain compounds that are toxic to the pathogen. The extracts of mango ginger could be explored further for developing a natural bactericide against $R$. solanacearum.
\end{abstract}

Keywords: bacterial wilt, essential oils, gas chromatography-mass spectrometry, mango ginger, rhizome extracts

\section{Introduction}

Bacterial wilt disease is caused by Ralstonia solanacearum (Smith), a soil-borne, rod-shaped gram-negative bacterium that affects hundreds of plant species, including many crops such as tomato, potato, tobacco, pepper, eggplant, banana, cowpea and peanut (Hayward 1991). In India, bacterial wilt of ginger has found a wide distribution resulting in almost 100\% yield losses (Dohroo 1991; Mathew et al. 1979). $R$. solanacearum could infect many ginger species without wounding and could survive for longer periods which show the potential risk it incurs in ginger growing areas (Paret et al. 2006). As ginger is an asexually reproducing plant, there is a lack of genetic variability among the accessions of ginger for disease resistance, which is one of the constraints in its genetic improvement. Resistance breeding in ginger is restricted to germplasm screening (Ravindran et al. 2005). The search for the resistance has been extended to other closely related genera in the family, Zingiberaceae such as Curcuma amada, C. longa, C. zedoaria, C. aromatica, Kaempferia galanga, Elettaria 
cardamomum and Zingiber zerumbet for their response to $R$. solanacearum. The Indian mango ginger (Curcuma amada Roxb.) exhibited significant resistance to $R$. solanacearum (Kumar et al. 2006; Prasath et al. 2011). A study on the factors governing the high level of resistance recorded in mango ginger to bacterial wilt may provide an opportunity for developing bacterial wilt resistance in ginger (Kumar et al. 2006).

The Indian mango ginger (C. amada) is aherbaceous perennial belonging to the family Zingiberaceae. It has a characteristic raw mango flavour which is mainly imparted by car-3-ene and cis-ocimene present in the essential oils (Achut \& Bandyopadhyaya 1984). It has antibacterial, insecticidal, antifungal and antioxidant properties (Jatoi et al. 2007). An antioxidant compound 'amadannulen' from the rhizome of mango ginger exhibited antimicrobial activity (Policegoudra et al. 2007). Amadannulen also showed antibacterial and bactericidal activities. In the present study biochemical analysis was carried out to study the mechanism of resistance of rhizome of mango ginger against $R$. solanacearum.

\section{Materials and methods}

\section{Collection of mango ginger rhizomes}

Fresh and healthy mango ginger rhizomes were collected from National Active Germplasm Site of ICAR-Indian Institute of Spices Research, Experimental Farm, Peruvannamuzhi, Kerala.

\section{Inoculum production and culture conditions}

The virulent strains of $R$. Solanacearum obtained from Division of Crop Protection, ICAR-Indian Institute of Spices Research were cultured on Casamino acid-Peptone-Glucose (CPG) agar medium supplemented with $0.005 \%$ (w/v) 2,3,5triphenyl tetrazolium chloride (TZC) medium at $28^{\circ} \mathrm{C}$ (Kelman 1954) and the colonies formed were multiplied in CPG broth for 16 hours. The broth was centrifuged and the bacteria were pelleted. The pellet was mixed with sterile water and made up to a concentration of $10^{8}$ cells $\mathrm{mL}^{-1}$.

\section{Preparation of rhizome extract}

The rhizomes of mango ginger were washed twice in sterile water, sliced and dried at $50^{\circ} \mathrm{C}$ for 3 days. The rhizome extract was prepared according to Policegoudra et al. (2006) with slight modifications. The dried rhizomes were powdered and $50 \mathrm{~g}$ of the powder was sequentially extracted with n-hexane, chloroform and methanol in the order of their increasing polarity at room temperature. All the chemicals used for extraction were of AR grade from Merck Ltd, Mumbai. After each extraction the solvents were filtered and concentrated using a rotary flash evaporator. The yields of extracts were noted $50 \mu \mathrm{L}$ of the solvent extracts were tested against $R$. solanacearum at different concentrations ranging from 5, 10, 25, 50, 75 $\mathrm{mg} \mathrm{mL}^{-1}$ and $100 \mathrm{mg} \mathrm{mL}^{-1}$. Dimethyl sulfoxide (DMSO) was used as negative control.

\section{Extraction of essential oil}

Essential oil was extracted from $500 \mathrm{~g}$ of dried and crushed mango ginger rhizomes by hydrodistillation using Clevenger type apparatus. The extracted essential oils were tested at 1\%, 5\% and $10 \%$ concentrations $(\mathrm{v} / \mathrm{v})$ against $R$. solanacearum.

\section{Antibacterial activity assay}

Antibacterial assay was carried out by agar well diffusion method (Valgas et al. 2007). $100 \mu \mathrm{L}$ of $16 \mathrm{hrs}$ old bacterial culture at OD- $0.1\left(10^{8} \mathrm{CFU}\right.$ $\mathrm{mL}^{-1}$ ) was spread on the surface of Casein Peptone Glucose (CPG) agar plates. Wells of 6 $\mathrm{mm}$ diameter were made with a sterile cork borer. $0.05 \mathrm{~mL}$ of extracts was added into the wells and allowed the extracts to diffuse. The control consisted of the DMSO alone and served as the negative control. The plates were incubated at $28^{\circ} \mathrm{C}$ for 48 to $96 \mathrm{hrs}$. Inhibition of the bacterial growth was measured in $\mathrm{mm}$.

\section{Statistical analysis}

For antibacterial assay test, a completely randomized design (CRD) was used with seven concentrations and three replicates. All the data were expressed as mean of three replicates and 
analysed using MSTATC software for analyses of variance (ANOVA).

Gas chromatography-mass spectrometry (GC-MS) analysis

The GC-MS analysis of the essential oil was performed using a Shimatzu GC-MS QP-2010, Column Rtx-5. Helium gas was used as the carrier gas at a constant flow rate of $1 \mathrm{~mL}$ $\mathrm{min}^{-1}$. The injection port temperature was set at $260^{\circ} \mathrm{C}$ and detector temperature at $250^{\circ} \mathrm{C}$. Oven was programmed for $60^{\circ} \mathrm{C}$ for $5 \mathrm{~min}$; up to $110^{\circ} \mathrm{C} @ 5^{\circ} \mathrm{C} \mathrm{min}^{-1}, 200^{\circ} \mathrm{C} @ 30^{\circ} \mathrm{C} \mathrm{min}^{-1}, 220^{\circ} \mathrm{C}$ $@ 5^{\circ} \mathrm{C} \mathrm{min}^{-1}$. For GC-MS detection an electron ionization system with ionization energy of 70 $\mathrm{eV}$, mass range of 60-450 amu and split ratio of 1: 40 was used.The relative percentage of the oil constituents was expressed as percentages by peak area normalization. Compounds were identified by matching the spectral fragmentation pattern of the compound with those stored in the National Institute of Standards and Technology (NIST) \& WILEY Library and mass spectra in Adams (1995).

\section{Results and discussion}

Plants are constantly exposed to a wide variety of pathogenic microorganisms. Plant diseases caused by bacteria and fungi significantly contribute to the overall loss in crop yield worldwide (Montesinos 2007; Savary et al. 2006). Plants have devised various strategies as defence mechanism against pathogens. Pesticides provide an effective control, but their threats to human health and the environment is adverse. Research focused on either introducing resistance into susceptible plants by transferring desired genes from wild relatives by gene transfer techniques or intensification of plant derived bactericides.The present study is investigated the antibacterial activity of mango ginger rhizome extracts. The sequential extraction with hexane, chloroform and methanol yielded 4.2, 0.9 and $2.8 \mathrm{~g}$ of extracts respectively. The preliminary screening of all the three extracts showed the same level of antibacterial activity against $R$. solanacearum as indicated by a clear zone of inhibition around the agar well supplemented with extract (Fig. 1 \& Table 1). The solvent extracts produced a zone of inhibition ranging from 3-9 $\mathrm{mm}$. The highest inhibition was found in the well supplemented with $0.05 \mathrm{~mL}$ of solvent extracts at a concentration of $100 \mathrm{mg} \mathrm{mL}^{-1}$. The inhibitory activity of the three extracts increased with the increase in concentration

Table 1. In vitro evaluation of extracts of mango ginger against $R$. solanacearum

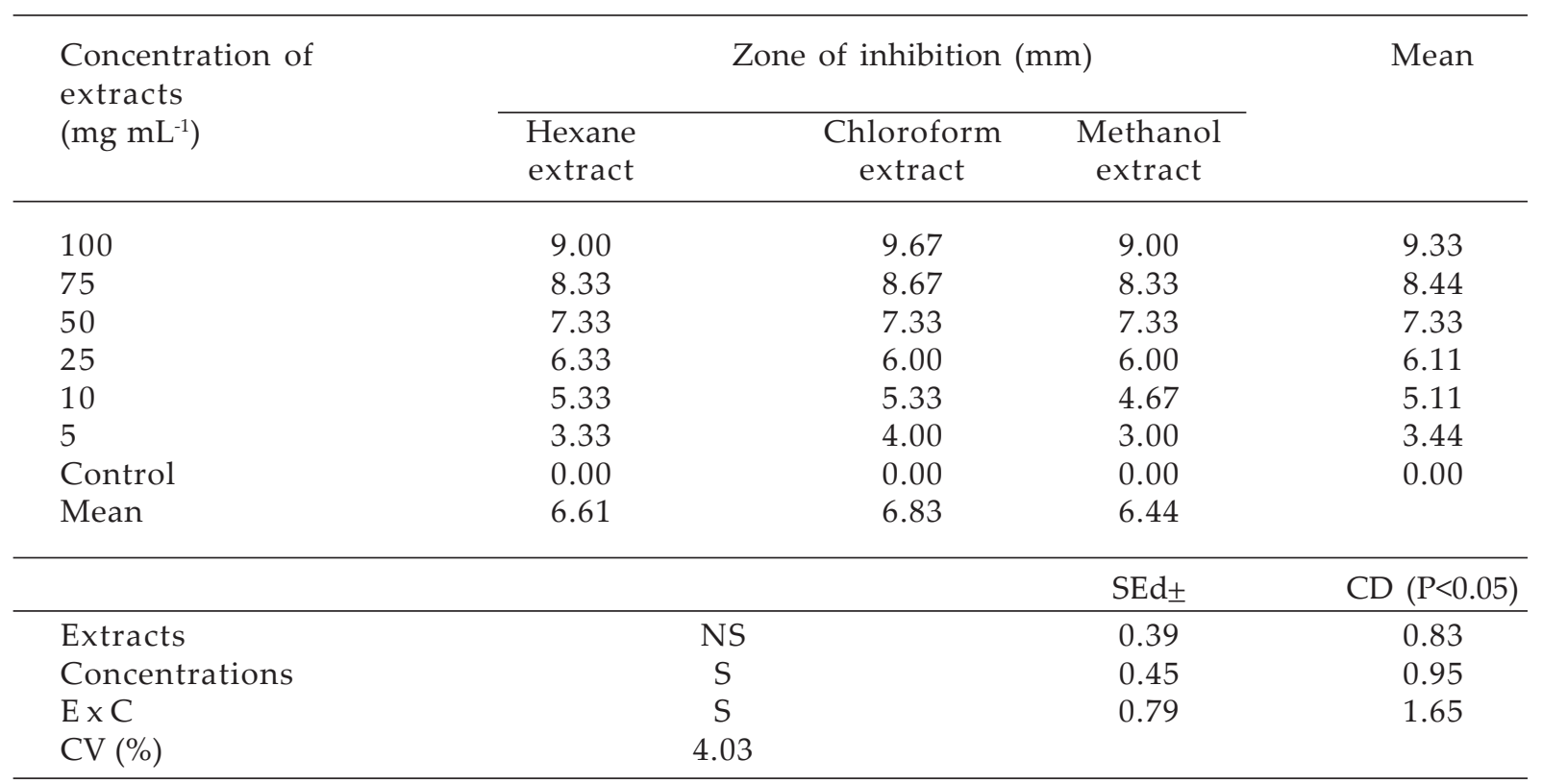




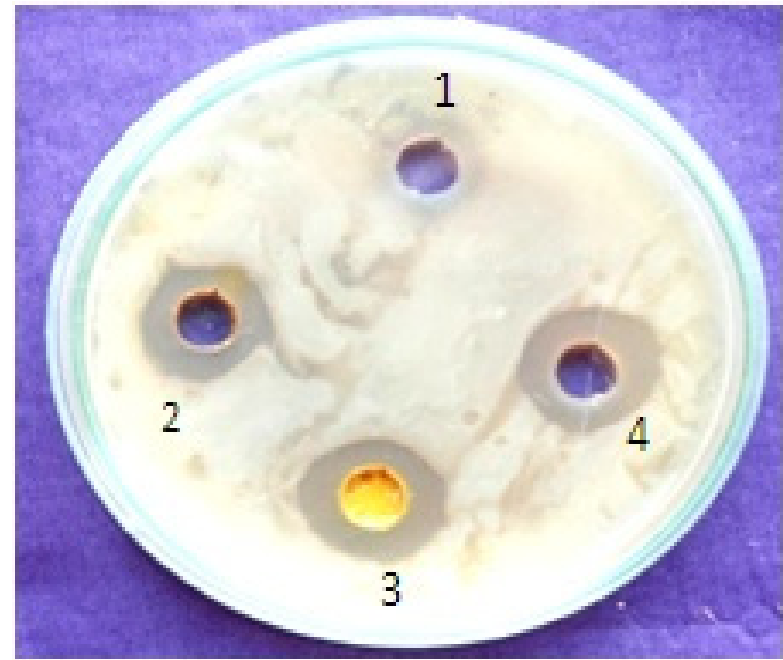

Fig. 1. Petriplate showing zone of inhibition of hexane $\left(75 \mathrm{mg} \mathrm{mL}^{-1}\right)$, chloroform $(75 \mathrm{mg}$ $\left.\mathrm{mL}^{-1}\right)$ and methanol $\left(75 \mathrm{mg} \mathrm{mL}^{-1}\right)$ rhizome extracts against $R$. solanacearum (1) Control (DMSO) (2) Hexane extract (3) Chloroform extract (4) Methanol extract

with reference to the control. The method of extraction did not show any significant variation with respect to the zone of inhibition.
Antibacterial activity of free and bound phenolics from mango ginger rhizomes has been reported by Siddaraju \& Dharmesh (2007). The antibacterial effect of different extracts like hexane, chloroform, ethyl acetate, acetone and methanol against human pathogen has been reported (Policegoudra et al. 2007). The volatile oil from mango ginger rhizome possesses antifungal properties (Singh et al. 2002). Difurocumenonol is a novel antibacterial compound that was effective against a wide range of gram-positive and gram-negative bacteria was isolated and characterized from mango ginger rhizome (Policegoudra et al. 2007).

Essential oils are potential source of novel antimicrobial agents especially against bacterial pathogens (Mitscher et al. 1987). Essential oils from mango ginger rhizome exhibited antibacterial activity at $1 \%, 5 \%$ and $10 \%(\mathrm{v} / \mathrm{v})$ against $R$. Solanacearum (Fig. 2). The antibacterial activity of the essential oils increased with the increase in concentration. GC-MS analysis identified the chemical constituents of the essential oils. Myrcene and
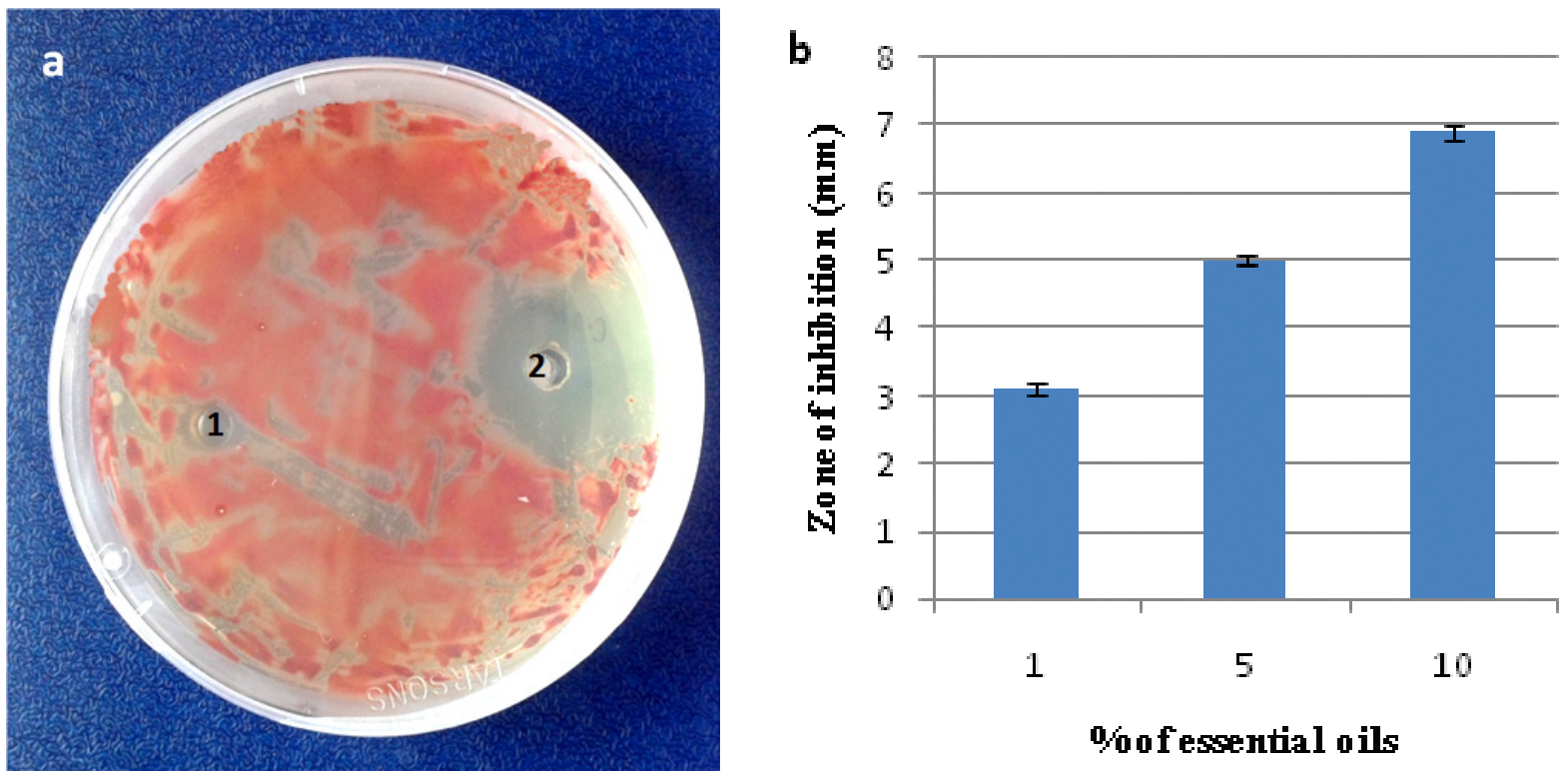

\%of essential oils

Fig. 2a. Petriplate showing the zone of inhibition essential oil of mango ginger against $R$. Solanacearum (1. Control; 2. Essential oil)

Fig. 2 b. Inhibitory activity of essential oils against $R$. solancaearum 
pinene were the major constituents of the essential oils (Table 2). It was earlier reported that myrcene and pinene are responsible for antifungal activity against the wide range of fungi, viz., Curvularia palliscens, Aspergillus niger, A. terreus, Fusarium moniliforme and F. falcatum (Policegoudra et al. 2007). The results show that the extracts from mango ginger rhizomes possessed antibacterial activity against $R$. solanacearum, confirming the great potential of bioactive compounds present in it. It is concluded that the essential oil and extracts from mango ginger could be explored further for developing a novel natural bactericide to manage bacterial wilt caused by $R$. solanacearum.

In the present work volatile oils and three solvent extracts (hexane, methanol and

Table 2. GC-MS analysis on composition of dried mango ginger rhizomes

\begin{tabular}{lc}
\hline Constituent & Area $(\%)$ \\
\hline$\beta$-Myrcene & 38.00 \\
$\beta$-pinene & 10.28 \\
Perillene & 3.74 \\
Caryophyllene oxide & 2.65 \\
Camphene & 1.98 \\
Cis-ocimene & 1.77 \\
D-limonene & 0.94 \\
$\alpha$ Terpineol & 0.91 \\
E-Caryophyllene & 0.90 \\
n-Hexadecanoic acid & 0.72 \\
1,8-Cineole & 0.65 \\
Camphene & 0.64 \\
Ar-Turmerone & 0.52 \\
Linalool & 0.46 \\
Geranial & 0.29 \\
2-Nonanone & 0.38 \\
Trans-ocimene & 0.33 \\
Cymene & 0.25 \\
Trans-Pinocarveol & 0.25 \\
Myrtenal & 0.21 \\
Borneol & 0.21 \\
Myrtenol & 0.20 \\
Perillyl alcohol & 0.20 \\
z-Citral & 0.17 \\
Curlone & 0.16 \\
Turmerone & 0.16 \\
\hline
\end{tabular}

chloroform) from the rhizome of mango ginger were evaluated in vitro against the bacterial wilt pathogen. All the three solvent extracts and essential oils possessed antimicrobial properties. GCMS analysis revealed that the major components of the essential oils were myrcene and pinene. As many terpenes are vital components of plant resistance to biotic and abiotic stresses (Kang et al. 2010; Rodriguez et al. 2011), in addition to myrcene and pinene, it is also possible that the trace/minor components present in essential oils, such as perillene, caryophylline oxide, camphene, limonene, terpineol etc. might be involved in some type of synergism with other active components of essential oil. The study concludes that the constituents of the rhizome of mango ginger might be inhibiting the entry of bacteria through the rhizome.

\section{References}

Achut S G \& Bandyopadhyaya C 1984 Characterization of mango-like aroma in Curcuma amada Roxb. J. Agric. Food. Chem. 32: $57-59$.

Adams R P 2007 Identification of essential oil components by gas chromatography/mass spectrometry (Ed 4), Allured publishing corporation, Carol stream, USA.

Dohroo N P 1991 New record of bacterial wilt of ginger in Himachal Pradesh. In: Indian Phytopathology, North Zone Meeting, 2930 April 1991 (pp.16), Central Potato Research Institute, Shimla, India.

Hayward A C 1991 Biology and epidemiology of bacterial wilt caused by Pseudomonas solanacearum. Ann. Rev. Phytopathol. 29: 6587.

Jatoi S A, Kikuchi A, Gilani S A \& Watanabe K A 2007 Phytochemical, pharmacological and ethnobotanical studies in mango ginger (Curcuma amada Roxb; Zingiberaceae). Phytotherapy Res. 21: 507-516.

Kang J H, Liu G, Shi F, Jones A D, Beaudry R M \& Howe G A 2010 The tomato odorless-2 mutant is defective in trichome-based production of diverse specialized metabolites and broad-spectrum resistance to insect herbivores. Plant. Physiol. 154: 262-272. 
Kumar A, Bhai R S, Sasikumar B, Anandaraj M \& Parthasarathy V A 2006 Curcuma amada Roxb. A bacterial wilt evading species in Zingiberaceae- A potential source of valuable genes for bacterial wilt resistance. In: Saddler G, Elphinstone J \& Smith J (Eds.) The $4^{\text {th }}$ International Bacterial wilt symposium, 17-20 July 2006 (pp.85), The Lakeside conference centre, CSL, York, UK.

Mathew J, Abraham K, Indrasenan G \& Samuel M 1979 A new record of bacterial wilt of ginger incited by Pseudomonas solanacearum E.F. Smith from India. Curr. Sci. 48: 213-214.

Mitscher L A, Drake S, Gollapudi S R \& Okwute S K 1987 A modern look at folkloric use of antiinfective agents. J. Nat. Prod. 50: 1025-1040.

Montesinos E 2007 Antimicrobial peptides and plant disease control. Microbiol. Lett. 270: $1-11$.

Paret M L, Sharma S K \& Alvarez A M 2012 Characterization of biofumigated Ralstonia solanacearum cells using micro-Raman spectroscopy and electron microscopy. J. Phytopathol. 102: 105-113.

Policegoudra R S \& Aradhya S M 2007 Biochemical changes and antioxidant activity of mango ginger (Curcuma amada Roxb.) rhizomes during postharvest storage at different temperatures. Postharvest. Biol. Technol. 46: 189-194.

Policegoudra R S, Divakar S \& Aradhya S M 2007 Identification of difurocumenonol, a new antimicrobial compound from mango ginger (Curcuma amada Roxb.) rhizome. J. Appl. Microbiol. 102: 1594-1602.

Prasath D, El-Sharkawy I, Sherif S, Tiwary K S \& Jayasankar S 2011 Cloning and characterization of PR5 gene from Curcuma amada and Zingiber officinale in response to
Ralstonia solanacearum infection. Plant Cell Rep. 30: 1799-1809.

Ravindran P N, Babu K N \& Shiva K N 2005 Botany and crop improvement of ginger. In: Ravindran $\mathrm{P} N$ \& Babu $\mathrm{K}$ N (Eds.) Monograph on ginger (pp.15-85), CRC Press, Boca Raton.

Rodriguez A, San Andres V, Cervera M, Redondo A, Alquezar B, Shimada T, Gadea J, Rodrigo M J, Zacarias L, Palou L \& Lopez M M 2011 Terpene down-regulation in orange reveals the role of fruit aromas in mediating interactions with insect herbivores and pathogens. Plant Physiol. 156: 793-802.

Savary S, Teng P S, Willocquet L \& Nutter F W 2006 Quantification and modeling of crop losses:a review of purposes. Ann. Rev. Phytopathol. 44: 89-112.

Siddaraju M N \& Dharmesh S M 2007 Inhibition of gastric $\mathrm{H}, \mathrm{K}$-ATPase and Helicobacter pylori growth by phenolic antioxidants of Curcuma amada. J. Agri. Food Chem. 55: 7377-7386.

Singh G, Singh O P \& Maurya S 2002 Chemical and biocidal investigations on essential oils of some Indian Curcuma species. Prog. Crystal Growth Character. Mater. 45: 7581.

Singh G, Singh O P, de Lampasona M P \& Catalan C 2003 Curcuma amada Roxb - chemical composition of rhizome oil. Indian Perf. 47: 143-146.

Srinivas Rao A, Bandaru R \& Ramachandran S 1989 Volatile aroma components of Curcuma amada Roxb. J. Agri. Food Chem. 37: 740-743.

Valgas C, de Souza S M, Smania E F A \& Smania A 2007 Screening methods to determine antibacterial activity of natural products. Braz. J. Microbiol. 38: 369-380. 